\title{
Estudo de espólio cerâmico proveniente do interior de uma habitação almóada da alcáçova de Alcácer do Sal (Portugal)
}

\author{
Study of ceramic booty from the inside of an almohad housing in the \\ acazaba of Alcacer do Sal (Portugal)
}

Marta Isabel Caetano Leitão*

\begin{abstract}
RESUMO
Dá-se a conhecer um conjunto de cerâmicas, datáveis entre a segunda metade do século XII e primeira metade do XIII, exumadas no interior de uma habitação, entre os anos de 1993-1997, no decorrer de intervenções arqueológicas realizadas no Convento de Nossa Senhora de Aracoeli (anterior alcáçova muçulmana) em Alcácer do Sal e que permitiram datar aquele espaço do Período Almóada.
\end{abstract}

Palavras-chave: Cerâmica, Arqueologia Medieval Muçulmana, Período Almóada, Alcáçova, Habitação.

\section{INTRODUÇÃO}

Devido ao carácter de emergência das intervenções arqueológicas realizadas, entre os anos de 1993-1997, no Convento de Nossa Senhora de Aracoeli, a cargo do Instituto Português do Património Arquitectónico e Arqueológico (IPPAR) e da Direcção Regional de Cultura do Alentejo, procedeu-se à abertura de sondagens com a implantação de uma quadrícula e à identificação de cada uma das zonas existentes, mediante a atribuição de uma letra maiúscula (A-O) (PAIXÃO et al. 1994: p. 222). Deste modo, o espólio agora apresentado é proveniente do sector I, nomeadamente, de uma área de habitação que se encontrava no interior do espaço correspondente à anterior alcáçova muçulmana (Lám. I).

Foi seleccionada uma amostra significativa de 12 fragmentos cerâmicos, em termos de

\begin{abstract}
We present a set of ceramics, datable between the second half of the twelfth century and first half of the XIII, exhumed within a housing, between the years 1993-1997, in the course of archaeological excavations carried out in the Convent of Nossa Senhora de Aracoeli (former Muslim fortress) in Alcacer do Sal and which allowed dating the space of the Almohad period.
\end{abstract}

Keywords: Ceramics, Medieval Archaeology Muslim, Almohad Period, Alcazaba, Housing.

representatividade dos conjuntos encontrados no sector referido e ainda não estudados, optando-se, ainda, por incluir os 18 fragmentos provenientes deste mesmo sector, já publicados, em 2001, pelos arqueólogos, António Rafael Carvalho e António Cavaleiro Paixão, em artigo na obra Garb: Sítios islâmicos do sul peninsular, totalizando um conjunto de 30 fragmentos, visando datar e caracterizar aquele espaço no interior da alcáçova.

No que diz respeito às peças inéditas, já se encontravam, no momento da sua selecção, lavadas e inventariadas com a respectiva fórmula de inventário AS/CC/95/SETOR. NÚMERO DE INVENTÁRIO - Alcácer do Sal, Cerca Convento, ano de escavação, Sector e Número de Inventário marcada em cada uma delas. Procedeu-se, deste modo, ao seu registo fotográfico e à sua descrição por grupos funcionais, optando-se pelas designações 


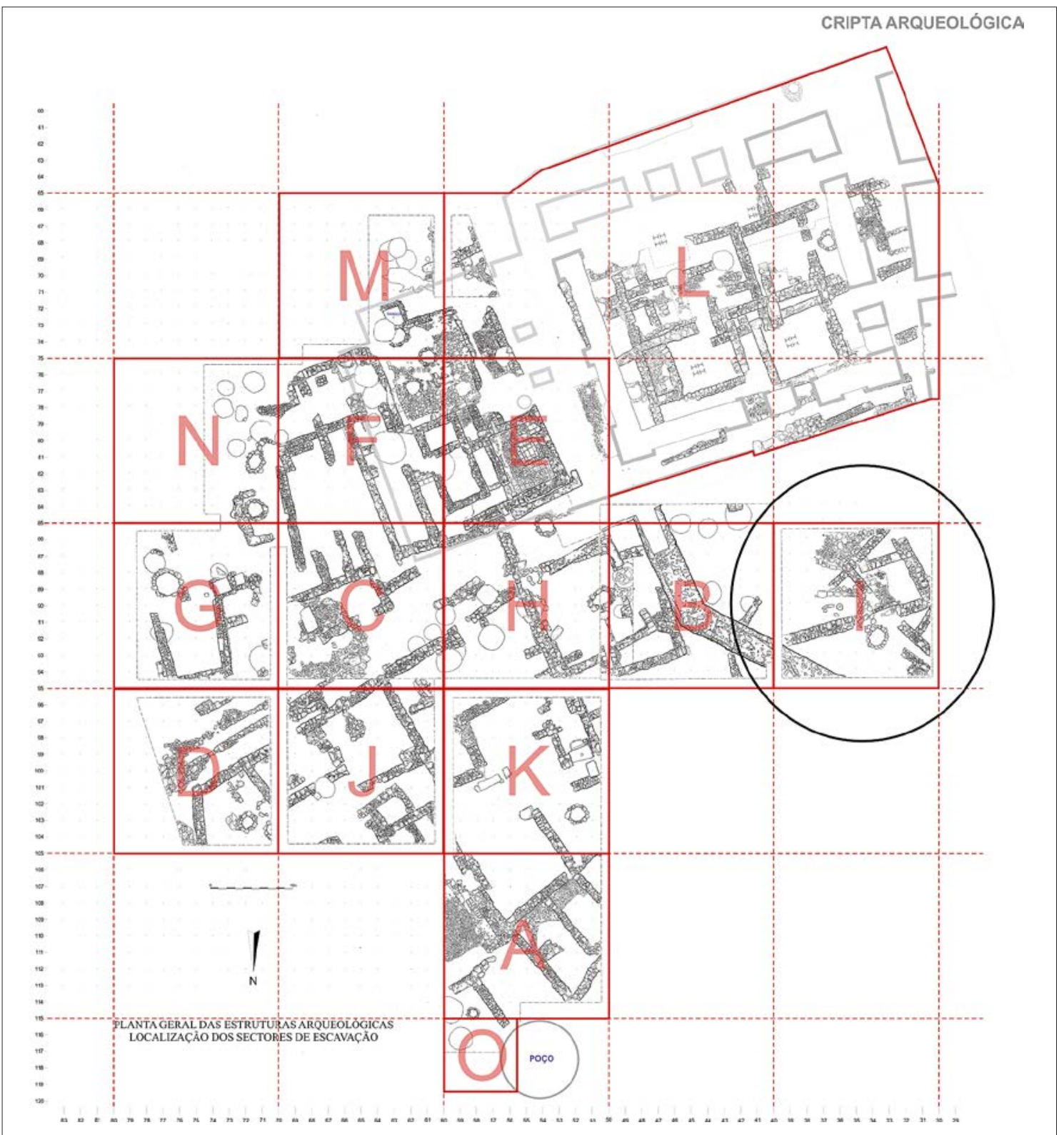

Lám. I. Localização do sector I na planta geral das estruturas identificadas (planta de Esmeralda Gomes, cedida pela Direç̧ão Regional de Cultura do Alentejo)

terminológicas propostas pela investigadora Rosa Varela Gomes, por se aproximarem dos termos utilizados actualmente, facilitando, ao mesmo tempo, a compreensão da imediata funcionalidade do objecto (GOMES, 2002: pp.34-44).

No conjunto de peças em estudo, possuímos: loiça de mesa, onde se integram as taças e jarras; na loiça de armazenamento, as talhas; no grupo dos contentores de fogo, as candeias; nas peças de uso complementar, dois testos e, em outros objectos, um fragmento de pia de abluções. Relativamente às 18 peças publicadas, utilizei as designações atribuídas pelo António Carvalho, que se enquadram nos grupos mencionados e incluem: loiça de mesa (taças e jarras), loiça de armazenamento (talha), loiça de cozinha (panela e alguidar) e contentores de fogo (lamparina e fogareiro).

O termo candil, vem do nome árabe qandîl, e designa a forma fechada das peças para iluminação, enquanto a utilização do termo candeia, refere-se à forma mais aberta, surgindo no al-Andalus a partir das últimas décadas 
do século XII, mantendo-se esta forma praticamente até à actualidade (GÓMEZ MARTÍNEZ, 2001a: p. 160; GOMES, 2002: p. 41).

As peças foram descritas segundo a sua forma de bordo e lábio, do corpo e do pé ou fundo, fazendo-se referência à sua decoração, quando existente, tratamento das superfícies, cor e tipo de pasta, sendo estas características apresentadas somente para a amostra das peças inéditas, dado as restantes 18 já se encontrarem descritas.

Relativamente à descrição das pastas, optou-se pela caracterização do conjunto total das 30 peças, tendo em vista conhecer o predomínio do tipo de pastas fabricadas no conjunto total da amostra. Os elementos não plásticos descritos segundo a sua identificação mineralógica (mica, feldspato, quartzo e pedaços de argila) e de acordo com a quantidade e tamanho, foram caracterizados de acordo com a definição elaborada pela investigadora Rosa Varela Gomes: elementos não plásticos com dimensões inferiores a $0,5 \mathrm{~mm}$, de grão finíssimo a fino formulam pastas muito homogéneas e compactas; de grão médio apresentam-se os elementos não plásticos medindo entre os $0,5 \mathrm{~mm}$ e os $1,0 \mathrm{~mm}$, constituindo pastas homogéneas e compactas. Pastas contendo elementos não plásticos com grão grosseiro, de dimensões superiores às anteriormente referidas, podendo atingir os 4,0 $\mathrm{mm}$, são, quase sempre, pouco homogéneas e não muito compactas (GOMES, 2002: p. 44).

\section{ESTRUTURAS IDENTIFICADAS}

As intervenções dentro da alcáçova muçulmana colocaram a descoberto uma série de estruturas que testemunham a ocupação humana no local ao longo de vários séculos. 0 sector I, de onde provêm as peças em análise, trata-se de um espaço que se encontra junto da muralha que separa a alcáçova da medina em Período Muçulmano e onde foi encontrada uma série de estruturas, relativas a distintos períodos cronológicos, desde a Idade do Ferro às Idades Medieval e Moderna (Lám. II).

No que diz respeito ao Período Muçulmano, foram descobertos dois muros, correspondentes a compartimento de uma habitação, que se encontravam dispostos perpendicularmente um ao outro, construídos com silhares de pedra e ligados nas juntas por terra e pedras de menores dimensões (Fig. 1). Um dos muros

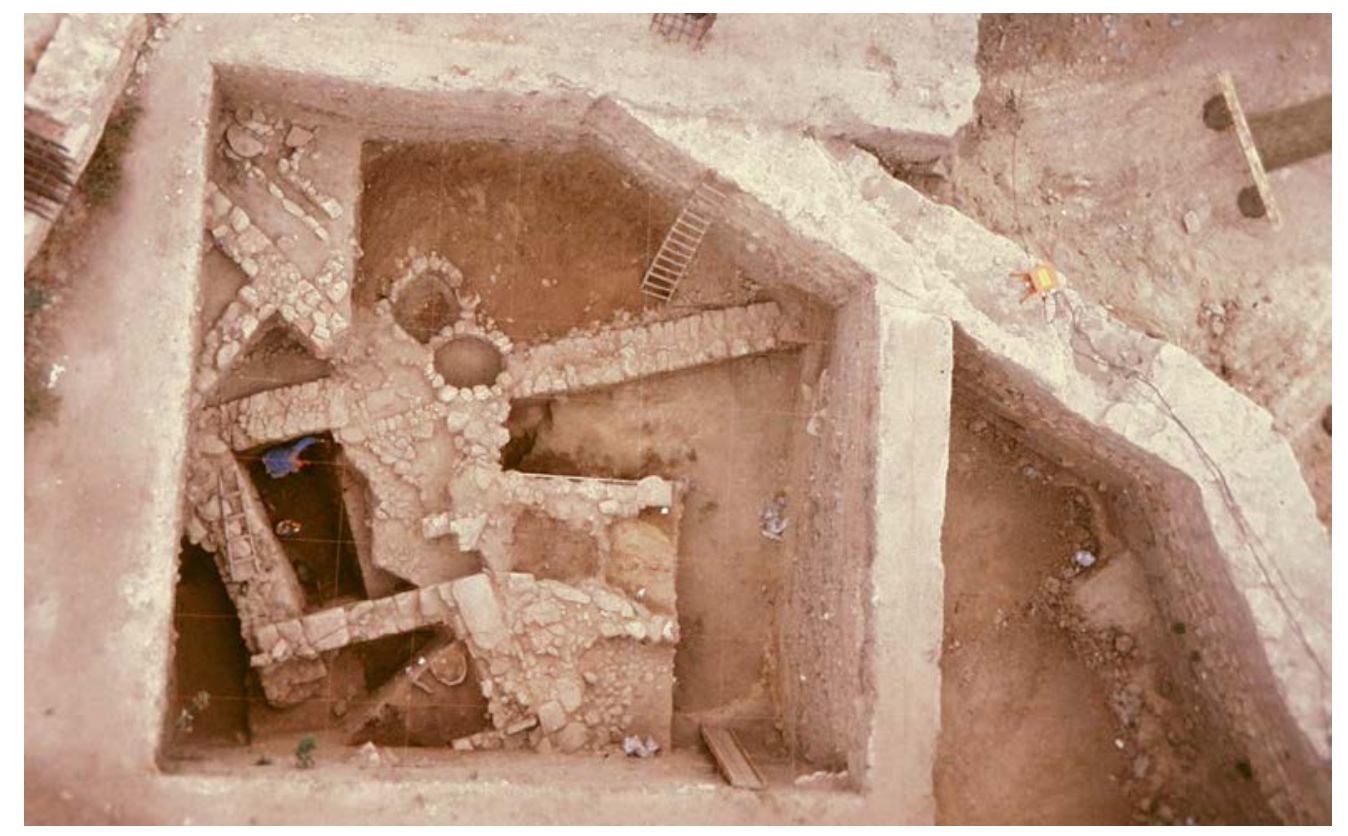

Fig. 1. Estruturas identificadas junto da muralha que separa a alcáçova da medina (fotografia de Manuel Perna cedida pelo Gabinete de Arqueologia da Câmara Municipal de Alcácer do Sal/ Direcção Regional de Cultura do Alentejo). 


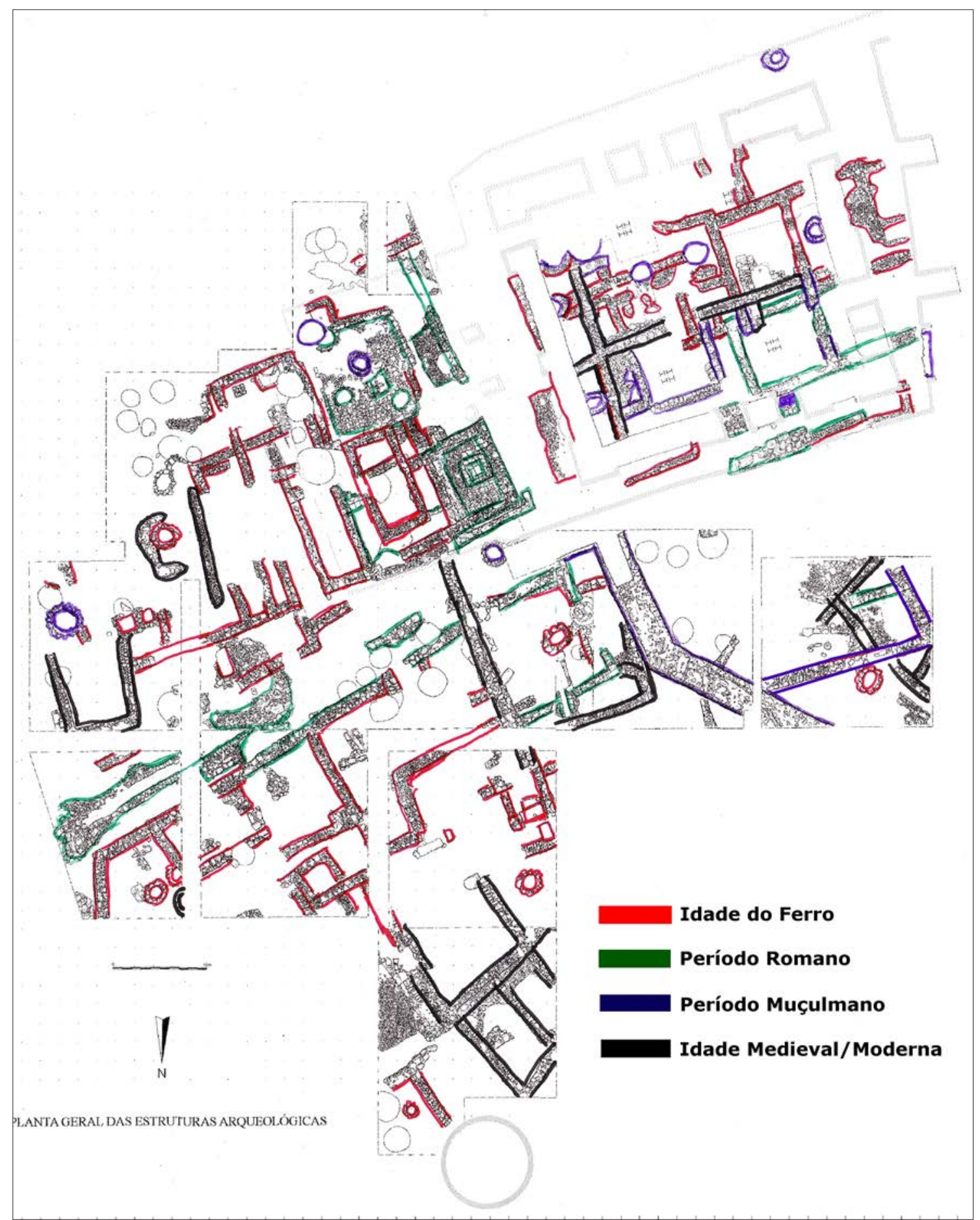

Lám. II. Planta geral com as estruturas individualizadas por períodos

(planta de Esmeralda Gomes, cedida pela Direcção Regional de Cultura do Alentejo.

Alterações nas cores das estruturas do sector I introduzidas por Marta Leitão).

encontrava-se orientado no sentido sul-norte e o outro no sentido este-oeste, achando-se neste último uma pequena abertura para o escoamento das águas pluviais (Fig. 2). Imediatamente acima daqueles descobriram-se muros alinhados datados das Idades Medieval e Moderna e um atribuído ao Período Romano. Todavia, o facto de este último se encontrar sobreposto aos muros islâmicos, indica a sua construção numa fase posterior e não na época romana, como os arqueólogos classificaram, tendo sido, provavelmente, construído 


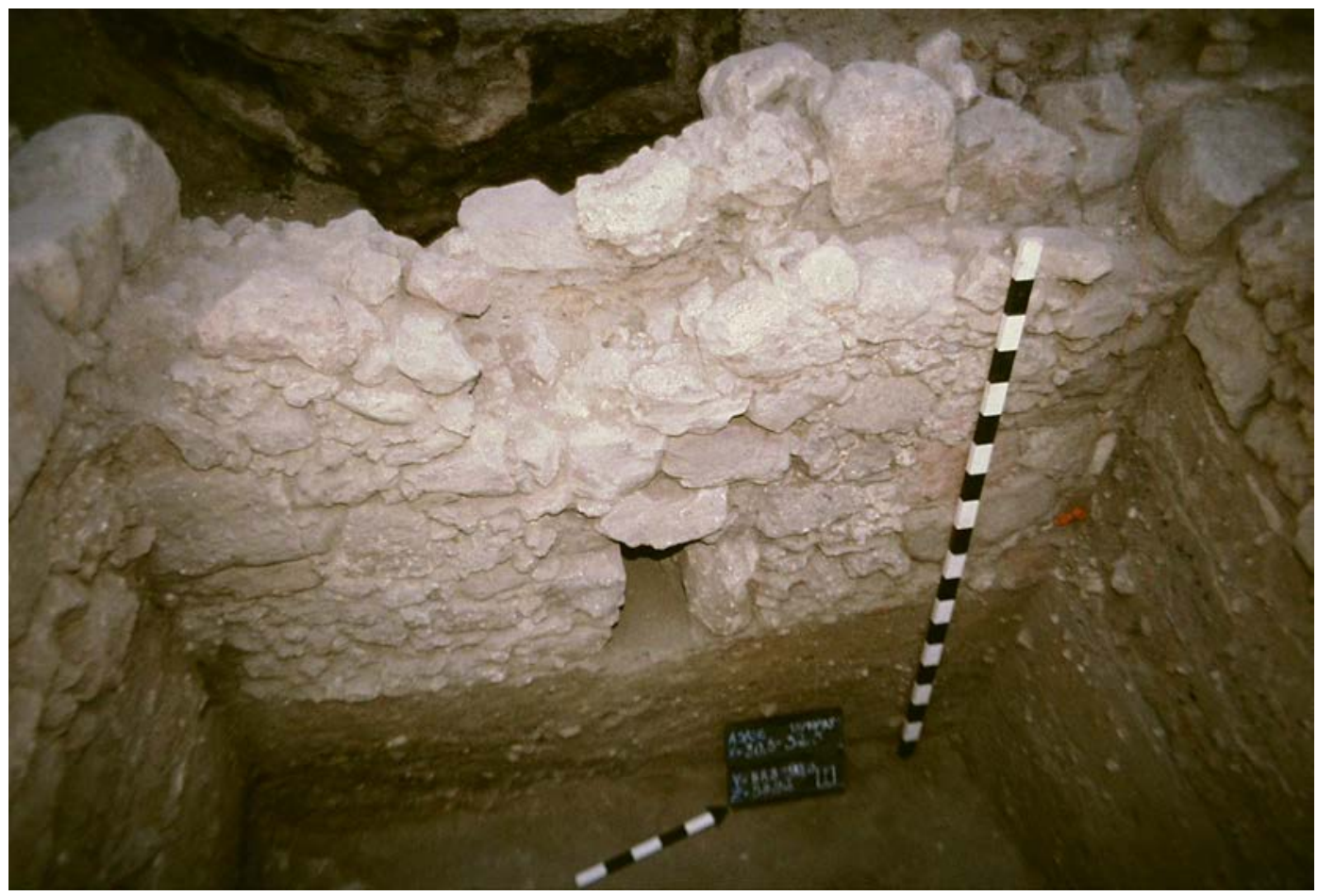

Fig. 2. Abertura para escoamento de águas identificada num dos muros

(fotografia de Manuel Perna cedida pelo Gabinete de Arqueologia da Câmara Municipal de Alcácer do Sal/ Direç̧ão Regional de Cultura do Alentejo).

com materiais provenientes do desmantelamento de estruturas daquele período (FARIA e PAIXÃO, 1996: pp. 9-25).

Um dos muros identificados define uma zona de cozinha, não escavada na totalidade, conforme denunciam as marcas de fogo e lareira no local, que possivelmente terá sido edificada durante a ocupação cristã na cidade. Para além das estruturas referidas, foram ainda encontrados dois silos, datáveis da Idade do Ferro, junto de uma das paredes da habitação muçulmana, nomeadamente o muro que segue no sentido sul-norte.

\section{ESPÓLIO CERÂMICO}

\section{Análise por grupos funcionais, para- lelos e cronologias}

\section{LOIÇA DE MESA}

Inserem-se neste grupo 4 taças que passarei a descrever individualmente:
- Taça (AS/CC/95/I.468) com bordo extrovertido, possuindo um corpo cilíndrico curvo com duas asas horizontais coladas à parede e uma base convexa. O seu diâmetro é de $12 \mathrm{~cm}$ e as paredes têm $1,1 \mathrm{~cm}$ de espessura máxima. Apresenta uma pasta de tom alaranjado, compacta e homogénea, contendo elementos não plásticos de grão médio fino e as superfícies foram cobertas com vidrado de tom melado (castanho claro obtido através do óxido de ferro), apresentando ainda a peça, marcas de fogo na superfície externa, conferindo um tom esverdeado ao vidrado, marcas essas, distribuídas ao longo da base do corpo (Fig. 3).

Este aspecto mostra-nos que em determinado momento, esta peça destinada a ser colocada a servir à mesa com alimentos ou líquidos, passou a ser utilizada para cozinhar. A nível decorativo encontra-se a marcação de caneluras paralelas em redor do corpo. Esta taça integra-se nas produções típicas do Período Almóada, 


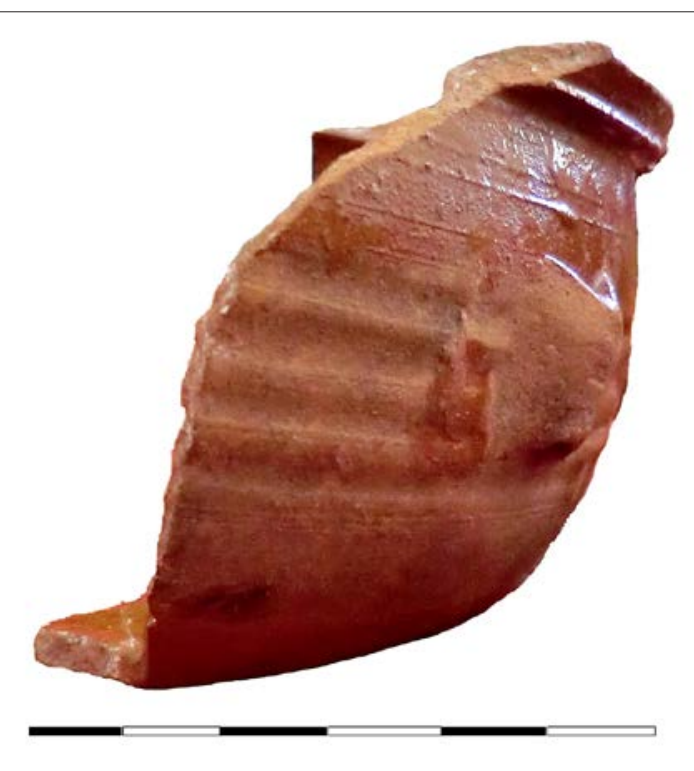

Fig. 3. Taça vidrada (fotografia de Marta Leitão).

com paralelos com exemplares recolhidos na encosta do Castelo de Mértola (GÓMEZ MARTINÉZ, 2001a: p. 155), enquadrandose cronologicamente entre a segunda metade do século XII e primeira metade do século XIII.

- Fragmento de taça com carena acusada (AS/CC/95/I.1179), nomeadamente uma porção do bordo, corpo e pé anelar. Possui um bordo vertical curvo com lábio semicircular, corpo bitroncocónico com uma acentuada carena e base convexa com pé anelar diagonal. O seu diâmetro é de $20,8 \mathrm{~cm}$ e as paredes têm 0,5 cm de espessura máxima. Apresenta uma pasta vermelha, homogénea e compacta, com elementos não plásticos de grão médio e fino, nomeadamente quartzo leitoso e mica, tendo a pasta sido coberta por uma espessa camada de vidrado de cor castanha e aspecto melado.

No Período Almóada são muito comuns este tipo de taças carenadas, com ou sem decoração a manganês, encontrando o exemplar paralelos com várias peças descobertas em vários sítios do al-Andalus, como Mértola, Silves, Alcácer-Ceguer e Castelo de Salir, sendo possível datá-las entre a segunda metade do século XII e primeira metade do século XIII (Catarino, 1997: p. 494; Gomes, 1988: p. 144; Gómez Martinéz, 2001a: p. 144) (fig. 4).

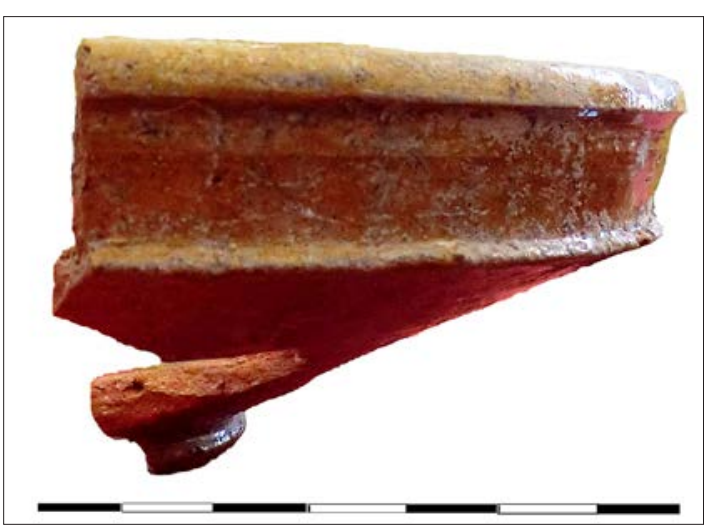

Fig. 4. Taça vidrada carenada (fotografia de Marta Leitão).

- Taça hemisférica (AS/CC/95/I.459) com bordo vertical arredondado, corpo semiesférico e base convexa com pé anelar diagonal com uma altura de $1 \mathrm{~cm}$. O seu diâmetro é de $11,5 \mathrm{~cm}$ e as paredes têm $0,8 \mathrm{~mm}$ de espessura máxima. Tanto a superfície interna, como a externa, foram cobertas com uma camada de vidrado bastante espesso, melado acastanhado muito brilhante. A pasta é vermelha, homogénea e compacta, com elementos não plásticos de grão médio e fino, nomeadamente quartzo leitoso e mica. Trata-se de um exemplar com paralelos em Silves, Mértola e Múrcia, com uma datação entre a segunda metade do século XII e primeira metade do século XIII (PALAZÓN, 1986: p. 227; GÓMEZ MARTíNEZ, 2001a: p. 144; GOMES, 2003: p. 222) (fig. 5).

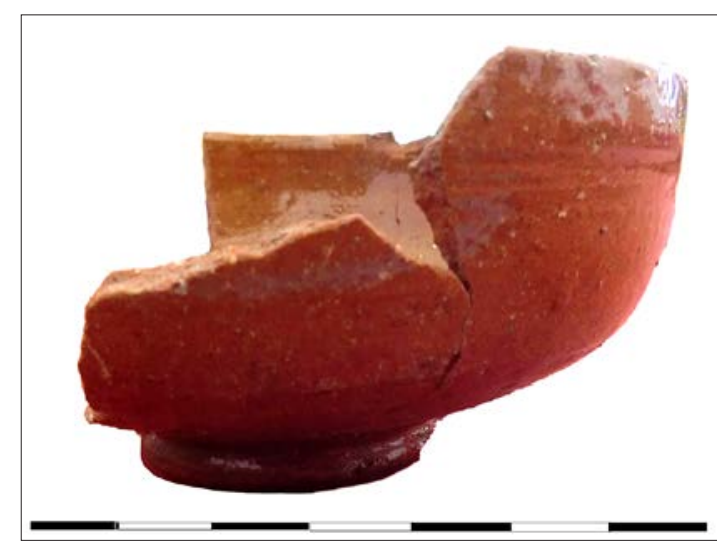

Fig. 5. Taça vidrada hemisférica (fotografia de Marta Leitão). 
- Fragmento de taça (AS/CC/95/I.440) com porção do bordo introvertido e lábio com secção semicircular, corpo bitroncocónico e base convexa. O seu diâmetro é de 14,6 $\mathrm{cm}$ e as paredes têm $1,1 \mathrm{~cm}$ de espessura máxima. A pasta é vermelha, homogénea e compacta, com elementos não plásticos de grão médio e fino (quartzo leitoso e mica), encontrando-se o fragmento revestido, tanto no interior, como no exterior, por uma espessa camada de vidrado castanho e de aspecto melado muito aderente e brilhante. Na sua superfície externa são visíveis cordões verticais em relevo, partindo da zona abaixo do bordo até à carena. Aqueles encontram-se separados entre si a uma distância que oscila entre 2,4 e 3,5 cm.

Este tipo de taças com cordões verticais foram bastante difundidas por todo o al-Andalus no Período Almóada, sendo encontradas praticamente em todas as estações arqueológicas da metade ocidental da península, como são o exemplo de Mértola, Silves, Salir e Niebla, enquadrando-se os exemplares numa cronologia entre a segunda metade do século XII e primeira metade do século XIII (BEDIA e MACIAS, 1993: p. 57; CATARINO, 1997: p. 494; GOMES, 1988: p. 144; GÓMEZ MARTÍNEZ, 2014a: p. 112) (fig. 6).

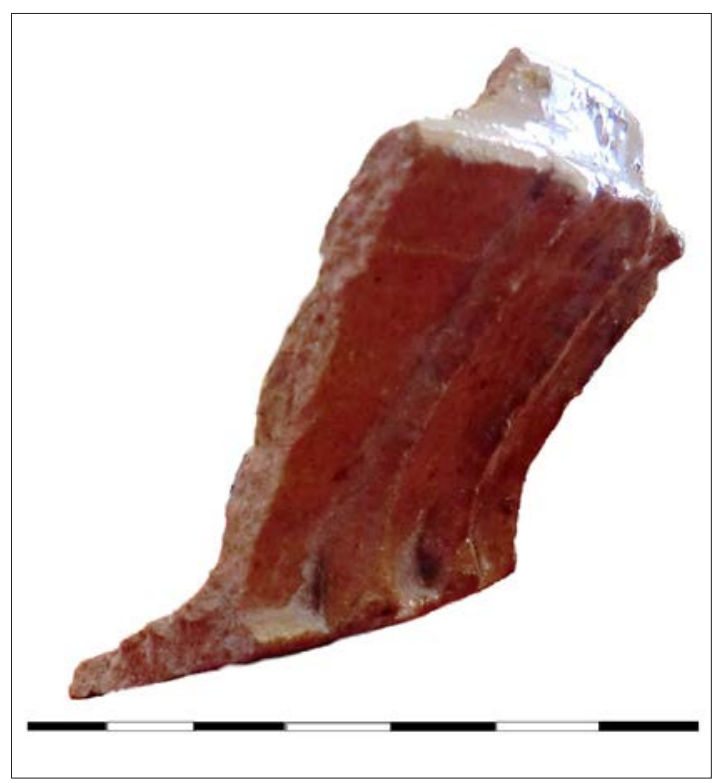

Fig. 6. Taça vidrada com cordões verticais (fotografia de Marta Leitão).
Para além das taças referidas, insere-se ainda neste grupo, um fragmento de jarra (AS/ CC/95/I.1182) com porção possivelmente do corpo (Fig. 7). As suas paredes têm uma espessura máxima de 0,4 mm. Apresenta pasta clara de tom bege, muito homogénea e compacta, com elementos não plásticos muito finos, tendo sido o fragmento coberto com engobe negro na sua superfície externa, aplicando-se sobre o mesmo uma linha de vidrado verde, seguido por debaixo da técnica de esgrafitado, através da marcação de várias linhas paralelas entre si e outras com curvaturas, encontrandose por debaixo das mesmas, uma outra linha de vidrado verde.

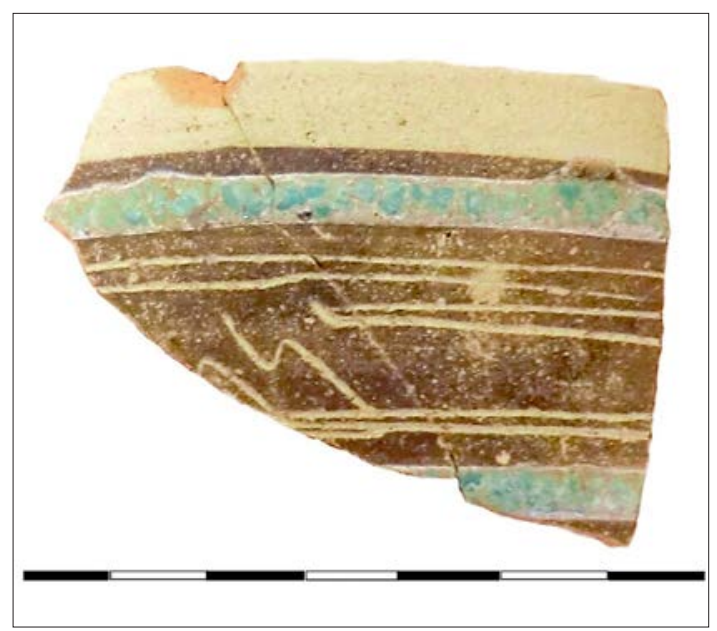

Fig. 7. Fragmento de jarra com decoração esgrafitada sobre engobe negro (fotografia de Marta Leitão).

A utilização do esgrafitado remonta ao século X em Nishapur e, tanto no Irão, como na Síria, estas peças utilizavam bandas epigrafadas e são atribuídas ao século XIII. Na Península Ibérica, nomeadamente no século XIII, em Múrcia, Ilha de Maiorca, Silves e Mértola, começa-se aplicar esta técnica decorativa sobre engobe negro, tratando-se, portanto, de uma produção do Período Almóada. A sua pouca representatividade e difusão na Península Ibérica sugerem que as mesmas terão sido importadas, tal como documentam as fontes escritas (GOMES, 1988: pp. 145-146; GÓMEZ MARTÍNEZ, 2005: 225; 2006: p. 104; CATARINO, et al., 2012: p. 439). O fragmento encontra paralelos com algumas peças encontradas em Mértola que combinam o 
esgrafitado sobre o engobe negro com o vidrado, assemelhando-se à técnica da corda seca parcial (GÓMEZ MARTíNEZ, 2006: p. 104).

\section{LOIÇA DE ARMAZENAMENTO}

Neste grupo inserem-se 2 fragmentos de talhas estampilhadas:

- Fragmento de talha (AS/CC/95/I.2268) com uma pasta clara de tom bege, compacta e homogénea, com elementos não plásticos de grão médio e fino de quartzo leitoso e mica. As suas paredes têm uma espessura máxima de $2 \mathrm{~cm}$. A nível decorativo foi aplicada, sobre a pasta, a técnica do estampilhado, encontrando-se na parte superior da peça uma banda com motivos geométricos, nomeadamente losangos, seguida de uma outra banda com motivos vegetalistas com um de cordão da vida contendo pétalas de flor no interior, seguindo-se de uma terceira banda com losangos (Fig. 8).

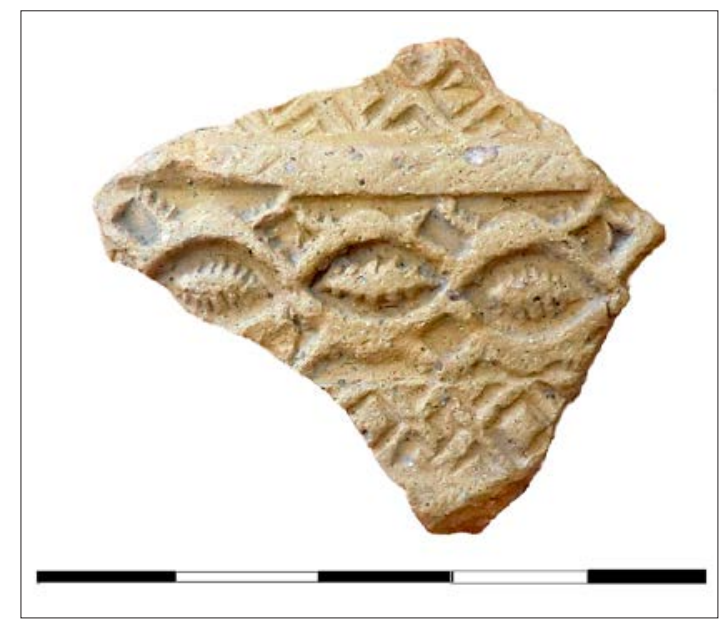

Fig. 8. Fragmento de talha estampilhada (fotografia de Marta Leitão).

- Fragmento de talha (AS/CC/95/I.1010) com pasta clara de cor bege, um pouco mais escuro que o fragmento anterior, compacta e homogénea, com elementos não plásticos de grão médio e fino de quartzo leitoso e mica. As suas paredes têm uma espessura máxima de 1,4 cm. À semelhança do fragmento anterior, também este foi decorado com estampilhas, apresentando na banda superior, motivos vegetalistas, seguindo-se uma banda sem decoração e uma outra com motivos fitomórficos e, por último, uma banda com elementos vegetalistas (Fig. 9).

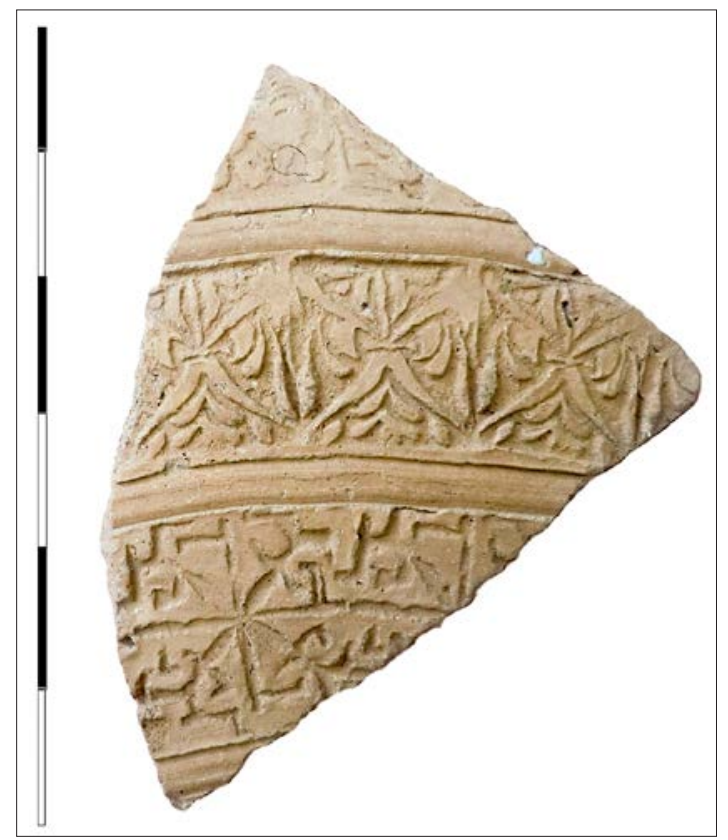

Fig. 9. Fragmento de talha estampilhada (fotografia de Marta Leitão).

Ambos os fragmentos de talha descritos apresentam paralelos com exemplares provenientes de outros locais do al-Andalus como Silves, Mértola e Castelo de Salir, enquadrando-se cronologicamente entre a segunda metade do século XII e a primeira metade do século XIII (CATARINO, 1997: p. 500; GÓMEZ MARTÍNEZ, 2001a: pp. 163-164; GOMES, 2003 : pp. 255-260).

Este tipo de peças era normalmente utilizado para conter líquidos, sendo pouco provável a sua utilização no armazenamento de produtos alimentares, como grãos e azeite, sendo adoptadas para esse fim as talhas lisas, que eram, por certo de mais baixo custo. Estas peças eram normalmente colocadas nos átrios de entrada e nos pátios das habitações.

\section{CONTENTORES DE FOGO}

Dentro deste grupo inserem-se duas peças para iluminação, dois fragmentos de candeias: 
- Fragmento de candeia (AS/CC/95/I.460) com porção de bordo extrovertido, corpo troncocónico invertido e base côncava. As suas paredes têm uma espessura máxima de $0,05 \mathrm{~mm}$. A pasta é de tom alaranjado, compacta e homogénea, com elementos não plásticos de grão médio e fino de quartzo e mica. A peça encontra-se coberta por uma espessa camada de vidrado de cor castanha e aspecto melado escuro e brilhante, sendo visíveis marcas de fogo no bico (Fig. 10).

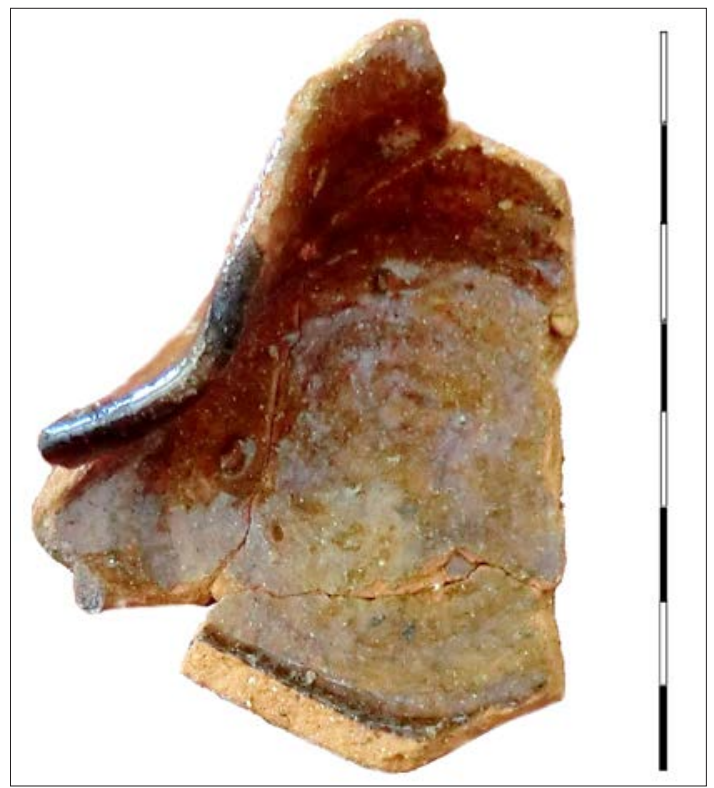

Fig. 10. Fragmento de candeia vidrada (fotografia de Marta Leitão).

- Fragmento de candeia (AS/CC/95/I.145) com porção do bordo, corpo troncocónico invertido e uma base plana, apresentando na sua superfície interna vestígios de asa vertical colada ao bordo e base. As suas paredes têm uma espessura máxima de $0,08 \mathrm{~mm}$. A pasta é de tom alaranjado, compacta e homogénea, com elementos não plásticos de grão médio e fino de quartzo e mica. O fragmento foi coberto, na superfície interna e externa, por um vidrado castanho e de aspecto melado mais claro que a peça anterior (Fig. 11).

Estas duas candeias enquadram-se nos modelos mais tardios da ocupação muçulmana, surgindo no al-Andalus, a partir das últimas

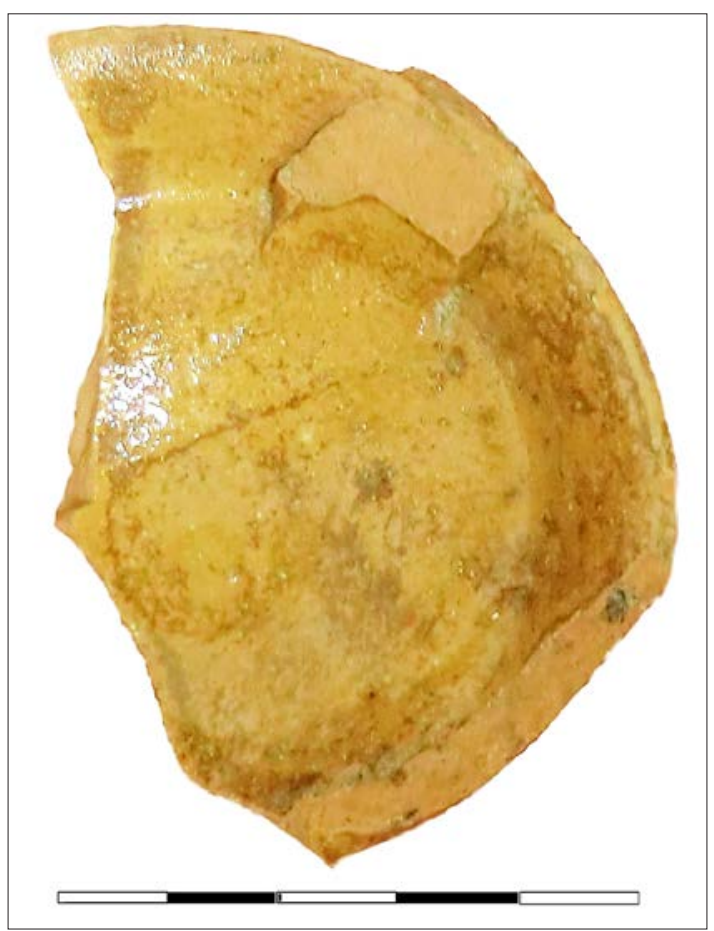

Fig. 11. Fragmento de candeia vidrada (fotografia de Marta Leitão).

décadas do século XII com evidentes influências orientais, tratando-se de uma forma mais aberta que o candil dos períodos precedentes. Peças semelhantes foram encontradas em Mértola, Silves, Salir e Múrcia, enquadrandose cronologicamente na primeira metade do século XIII (PALAZÓN, 1986: p. 197; CATARINO, 1997: p. 494; GÓMEZ MARTÍNEZ, 2001a: p. 160; GOMES, 2003: p. 242).

\section{PEÇAS DE USO COMPLEMENTAR}

Fazem parte deste grupo, dois testos praticamente iguais, com pastas claras, muito homogéneas e compactas, com elementos não plásticos de grão finíssimo. Uma das peças (AS/CC/95/I.143) encontra-se completa, possuindo forma troncocónica, bordo com lábio de secção semicircular, assentando em base plana, sendo visível pega em botão (Fig. 12). O seu diâmetro é de $12,1 \mathrm{~cm}$ e as paredes têm 0,4 cm de espessura máxima Relativamente à segunda peça (AS/CC/95/I.49) encontra-se fracturada, conservando-se, somente, a pega em botão, parte do bordo e lábio semicircular e a base plana (Fig. 13). 


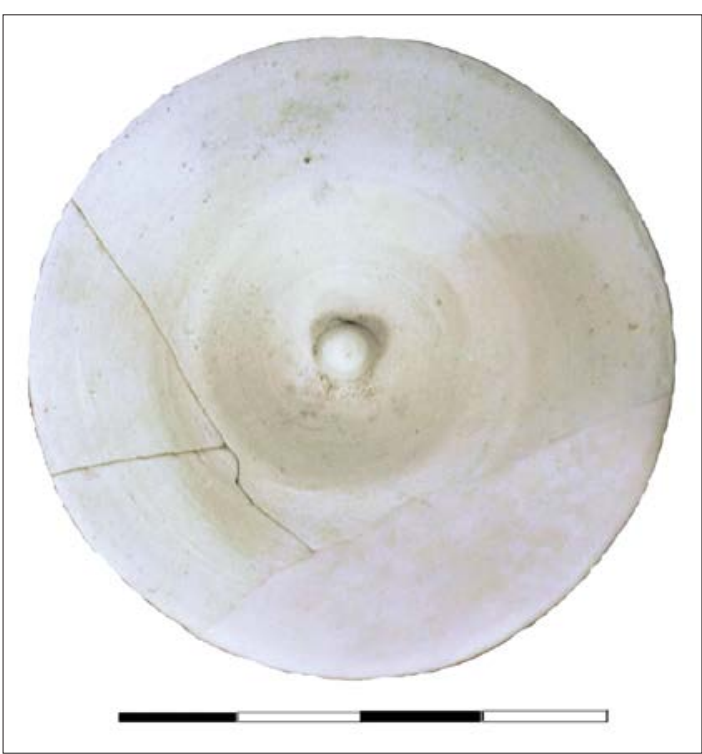

Fig. 12. Testo (fotografia de Marta Leitão).

Os testos eram normalmente utilizados, como tampa, para cobrir recipientes e são conhecidos para largos períodos históricos tornando-se difícil datá-los. Ainda assim, não queria deixar de mencionar a sua existência no contexto arqueológico em estudo, apresentando paralelos com testos de Múrcia datáveis do século XIII, podendo os exemplares mencionados enquadrar-se nessa cronologia (NAVARRO PALAZÓN, 1986: pp. 22 e 260).

\section{OUTROS OBJETOS}

Enquadrei neste grupo um fragmento de uma pia de abluções (AS/CC/95/I.1186) de formato rectangular e corpo com concavidades para conter líquidos no seu interior. As suas paredes têm uma espessura que oscila entre os 1,9 e os 2,6 cm. A pasta é clara, de tom bege, compacta e homogénea, com elementos não plásticos de grão médio e fino, nomeadamente feldspato, mica e pedaços triturados de argila (Fig. 14).

O fragmento encontra-se coberto por uma camada espessa de vidrado verde na sua superfície interna e bordo, descobrindo-se, nas partes mais largas do mesmo, decoração estampilhada que usou uma matriz com motivos florais, enquanto na sua superfície interna

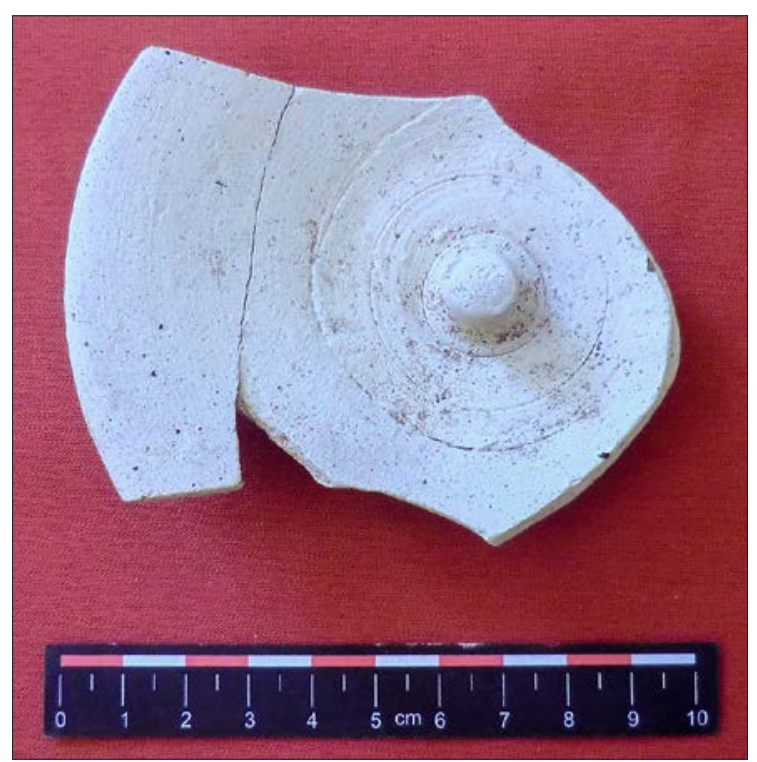

Fig. 13. Fragmento de testo (fotografia de Marta Leitão).

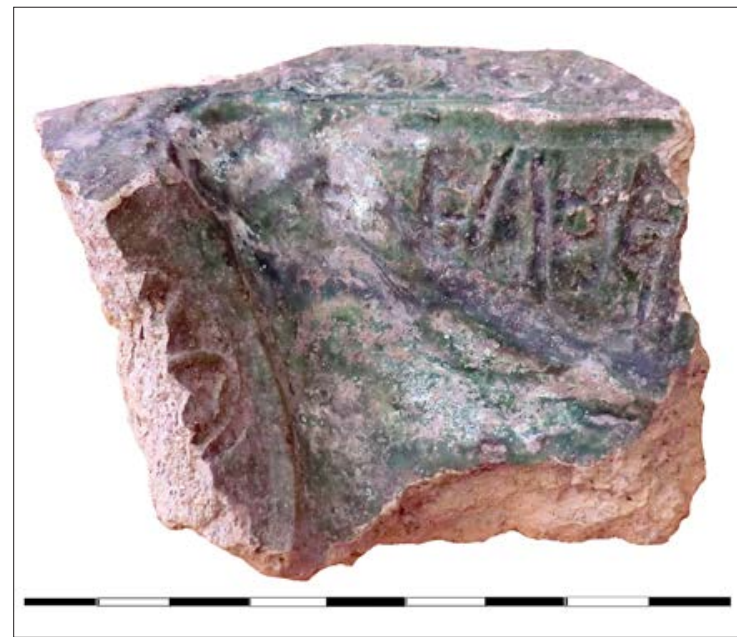

Fig. 14. Fragmento de pia de abluções (fotografia de Marta Leitão).

foi empregue uma matriz estampilhada epigráfica, possivelmente uma frase corânica, que infelizmente não se consegue decifrar por a peça estar fracturada. Esta combinação de técnicas decorativas é muito habitual durante a segunda metade do século XII e primeira metade do século XIII, assim como a combinação dos elementos vegetalistas com epigráficos, para além do facto de ser uma peça destinada a conter água, o que indica uma forte simbologia ligada com a purificação do corpo e do espírito (GÓMEZ MARTíNEZ, 2011: p. 81; GOMES, 2013: p. 78). 
Este exemplar tratar-se-ia, eventualmente, de uma peça de uso individual, dado que as abluções podiam ser realizadas em casa e não somente nas mesquitas, sendo muito habituais estes exemplares em cerâmica no Período Almóada. Um bom paralelo para esta peça encontra-se em Mértola, proveniente da alcáçova, enquadrando-se na cronologia referida, assim como a pia de abluções em mármore encontrada em Cacela, que contém igualmente frase corânica (GÓMEZ MARTíNEZ, 2011: p. 81; GOMES, 2013: p. 78).

\section{PEÇAS PUBLICADAS}

No que respeita ao conjunto de 18 peças que foram publicadas em 2001, pelos arqueólogos, António Cavaleiro Paixão e António Carvalho, no artigo contido na obra Garb: Sítios islâmicos do sul peninsular, do sector de escavação em estudo, inserem-se igualmente no âmbito cronológico entre a segunda metade do século XII e primeira metade do século XIII, portanto do Período Almóada.
Trata-se de quatro taças carenadas, três delas vidradas, de cor castanha e de aspecto melado, apresentando uma delas, decoração de cor castanha escura de óxido e manganês na superfície interna (AS/CC/95/I.156-438), (AS/CC/95/I.450), (AS/CC/95/I.443); uma outra é esmaltada, de cor verde na superfície interna onde oferece ornamentação estampilhada com representação de "mão de Fátima" (AS/ CC/95/I.1020); duas taças hemisféricas, uma delas vidrada a verde com pé anelar (AS/ cC/95/I.449) e uma outra com esmaltes de tom turquesa na superfície interna e verde-claro na superfície externa (AS/CC/95/I.442). Para além das taças mencionadas, foram também apresentadas quatro taças com cordões verticais, sendo duas vidradas de cor castanha e aspecto melado e duas sem qualquer tipo de vidrado, apresentando uma delas marcas de fogo, podendo, eventualmente, ter sido utilizada como frigideira (AS/CC/95/I.462), (AS/ CC/95/I.62), (AS/CC/95/I.459), (AS/CC/95/I.465) (Láms. III à V).

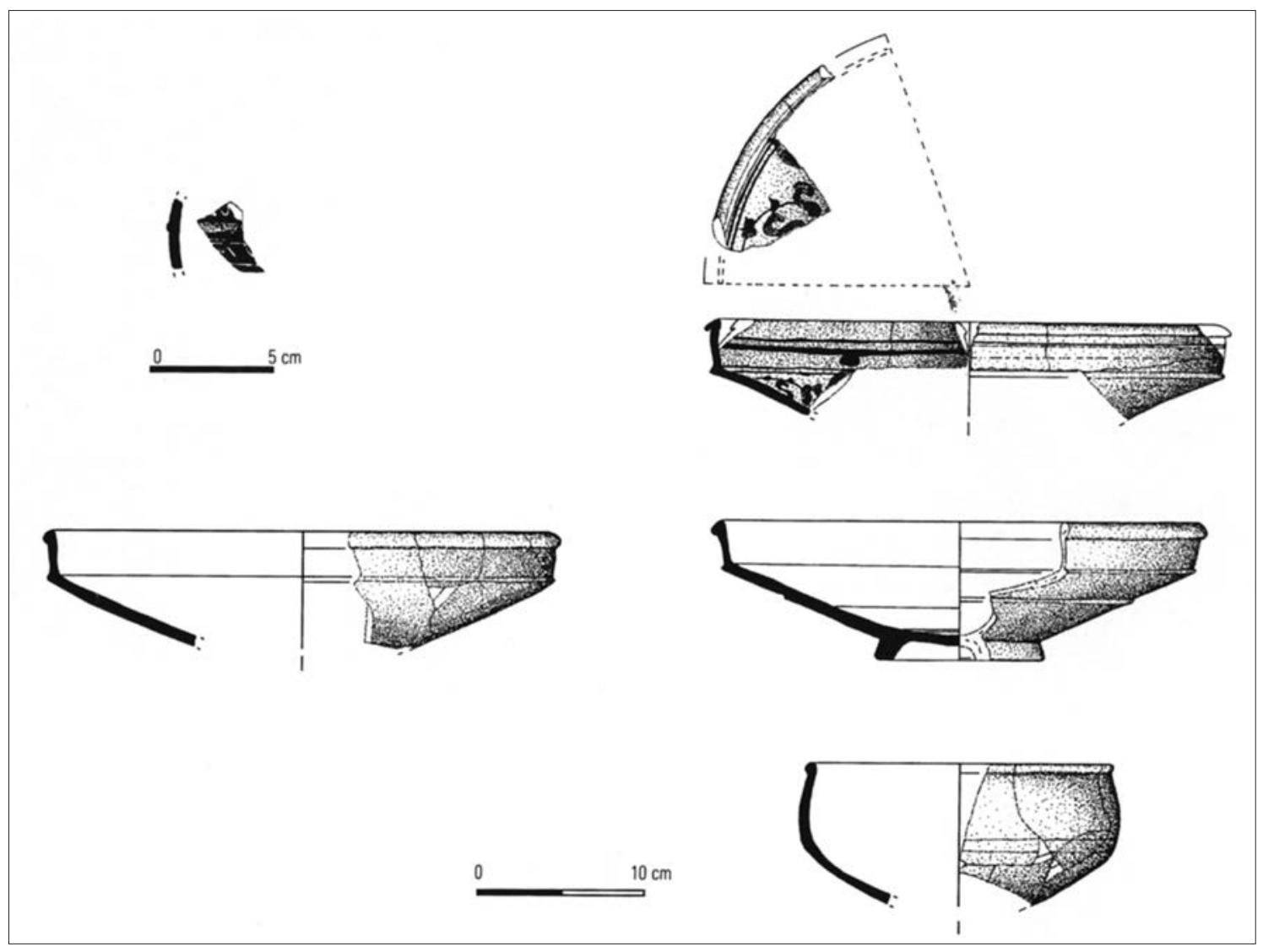

Lám. III. Taças carenadas, taça hemisférica e fragmento de jarra esgrafitada (desenhos de António Rafael Carvalho/Garb: Sítios islâmicos...pp. 211-229). 

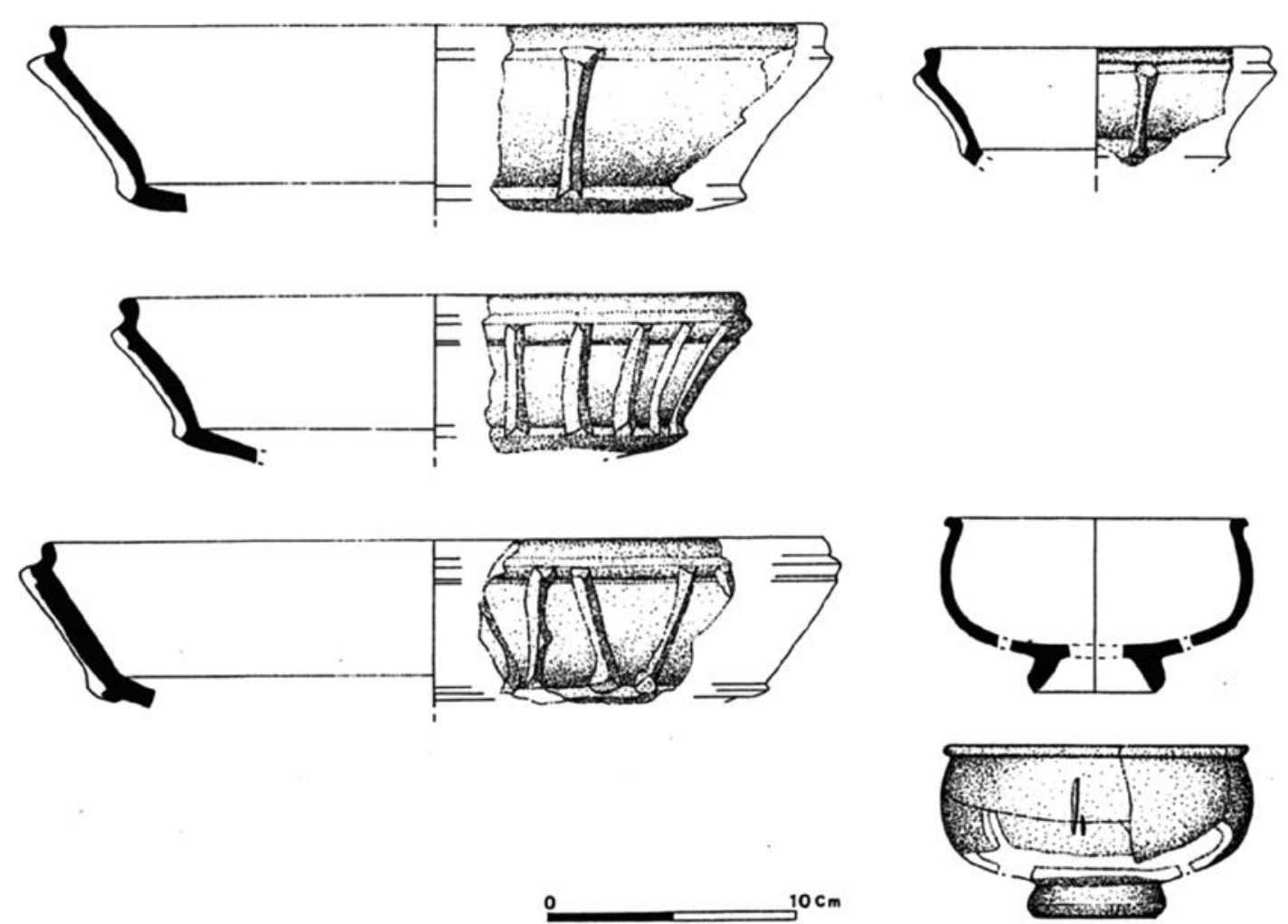

Lám. IV. Taças com cordões verticais e taça hemisférica com pé anelar (desenhos de António Rafael Carvalho/Garb: Sítios islâmicos... pp. 211-229)

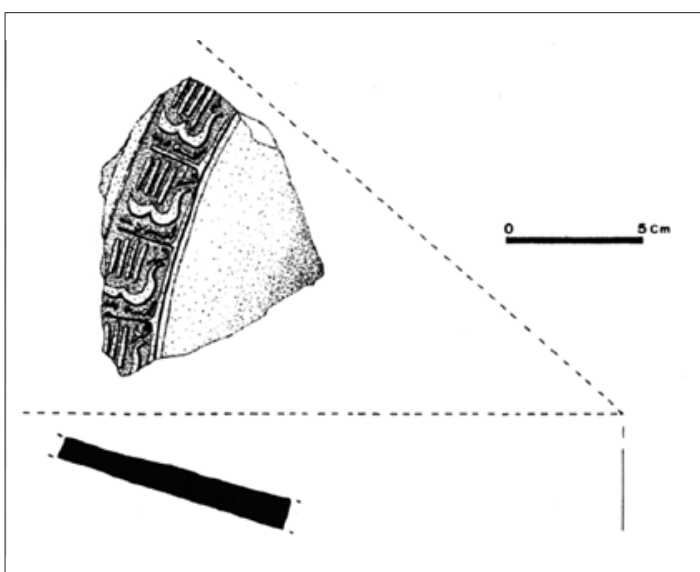

Lám. V. Fragmento de taça com representação da mão de Fátima (desenho de António Rafael Carvalho/Garb: Sítios islâmicos... pp. 211-229).

Ainda, no que respeita à loiça de mesa, insere-se um fragmento de jarra estampilhada com motivos vegetalistas e vidrada a verde (AS/CC/95/I.448), um fragmento de jarra moldada a relevo e revestida por vidrado branco com reflexos de dourado (AS/CC/95/I.999) e um fragmento de uma jarra esgrafitada com uma linha de vidrado verde, que possivelmente fará parte do fragmento de jarra esgrafitada mencionado anteriormente (AS/CC/95/I.441) (Láms. III e VI).

Relativamente à loiça de armazenamento temos um fragmento de talha vidrada a verde na sua superfície externa, com decoração incisa e estampilhada, nomeadamente motivos geométricos, fitomórficos e epigráficos (AS/ CC/95/I.2) (Lám. VII). Dentro da loiça de cozinha insere-se um fragmento de bordo e bojo de panela com caneluras (AS/CC/95/I.451) e um fragmento de alguidar (AS/CC/95/I.458) (Lám. VIII). Quanto aos contentores de fogo, foram apresentados a base de uma lamparina vidrada de cor castanha e aspecto melado (AS/ CC/95/I.463) e um fogareiro quase intacto (AS/ CC/95/I.445) (Lám. IX). 

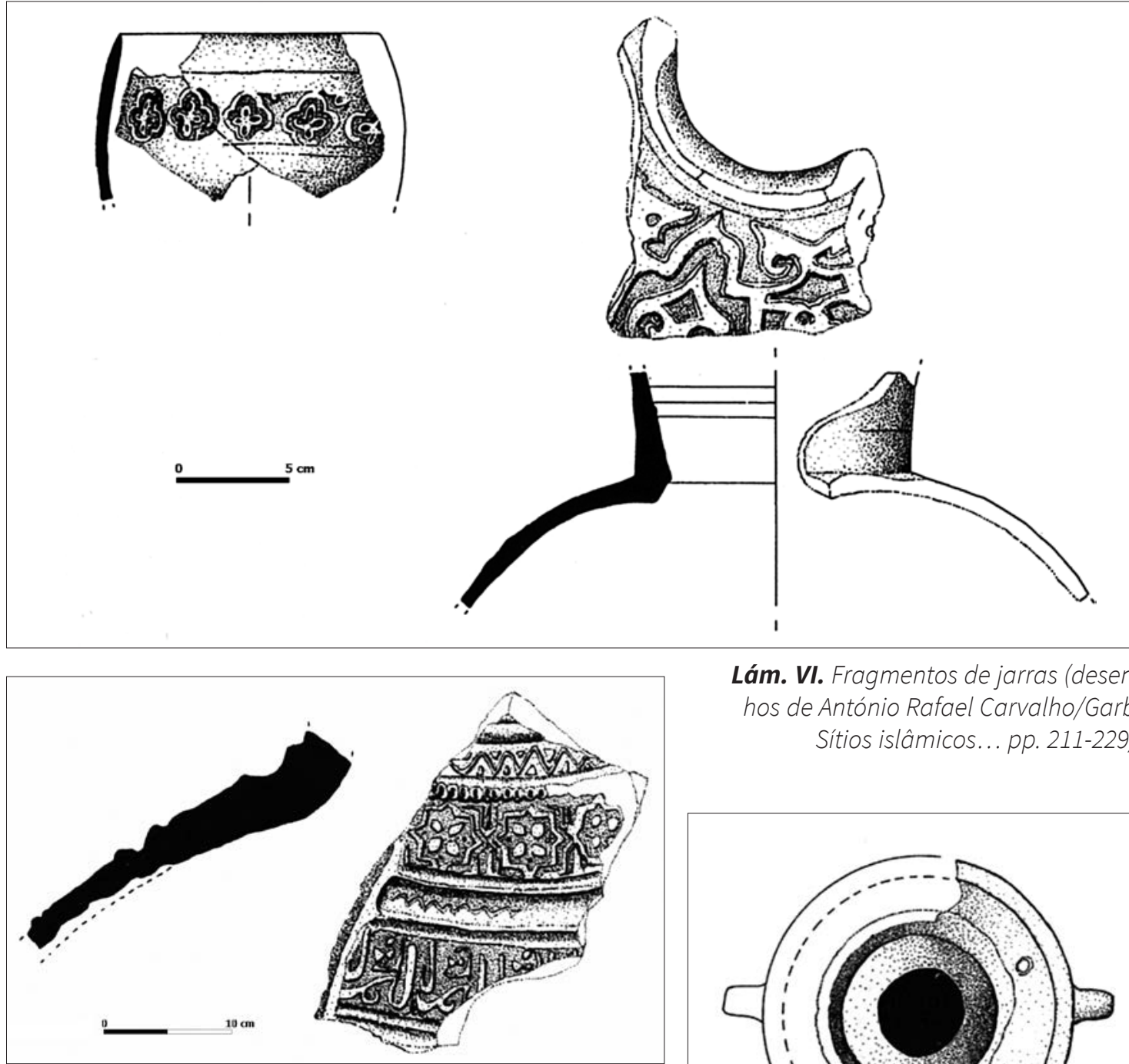

Lám. VI. Fragmentos de jarras (desenhos de António Rafael Carvalho/Garb: Sítios islâmicos... pp. 211-229).

Lám. VII. Fragmento de talha vidrada a verde com decoração estampilhada (desenho de António Rafael Carvalho/ Garb: Sítios islâmicos... pp. 211-229)

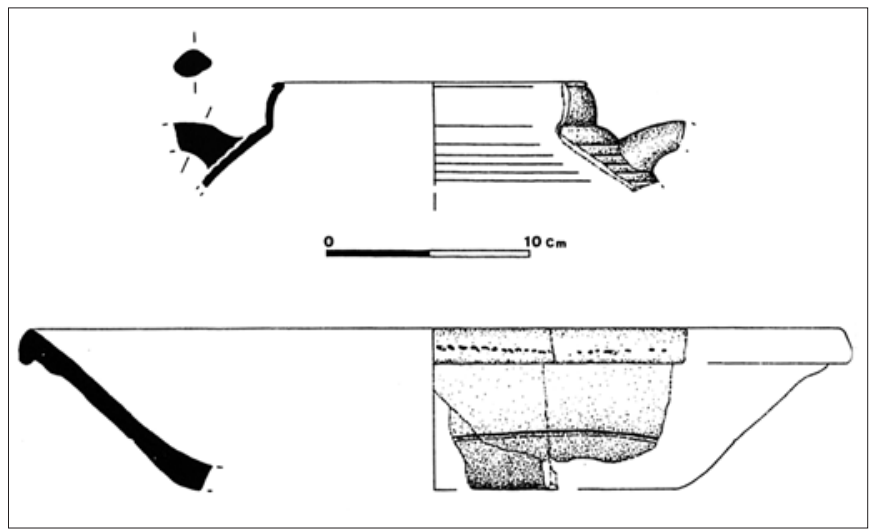

Lám. VIII. Fragmento de panela e alguidar (desenhos de António Rafael Carvalho/Garb: Sítios islâmicos... pp. 211-229).

Lám. IX. Fogareiro e fragmento de lamparina (desenhos de António Rafael Carvalho/Garb: Sítios islâmicos... pp. 211-229).

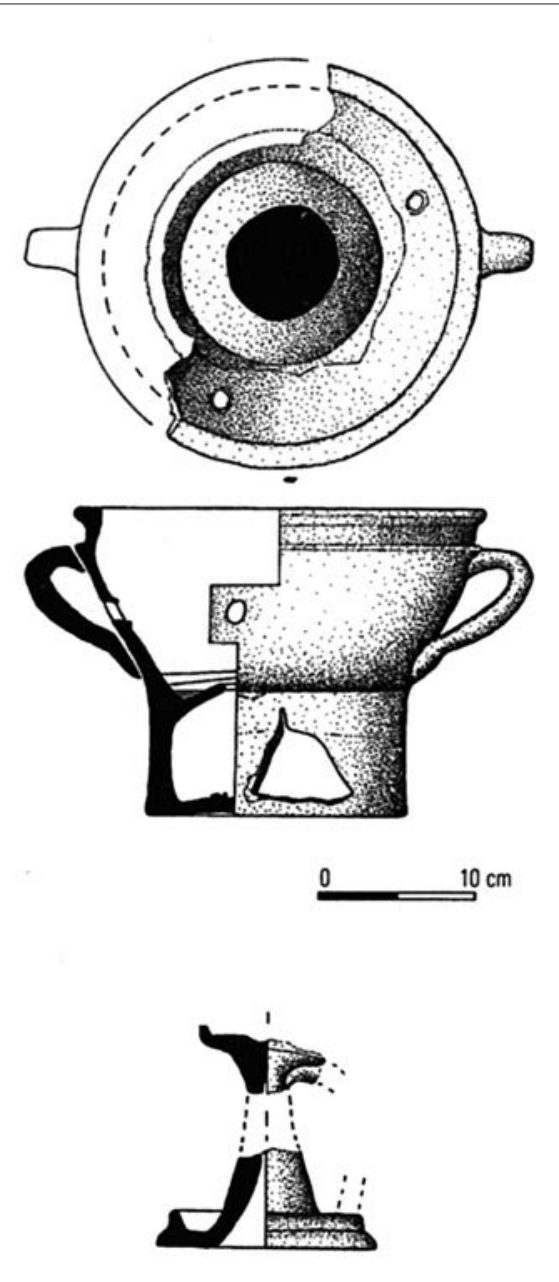




\section{Pastas, tratamento das superfícies, formas e decorações}

Agora, que já conhecemos na totalidade o conjunto da amostra das 30 peças de cerâmica encontradas no sector I da escavação, vamos fazer uma síntese das pastas, tratamentos das superfícies, formas e decorações que foram empregues. No que respeita às formas, há um predomínio de taças, contabilizando aquelas uma totalidade de catorze exemplares, seguindo-se de quatro jarras, três talhas, duas candeias, dois testos, uma lamparina, uma panela, um alguidar, um fogareiro e uma pia de abluções. Existe, portanto, dentro da amostra, um predomínio da loiça de mesa (17 exemplares), seguido dos contentores de fogo (4 exemplares), loiça de armazenamento (3 exemplares), loiça de cozinha (3 exemplares), peças de uso complementar (2 exemplares) e outros objectos (1 exemplar).

Relativamente ao tipo de pasta utilizada para a elaboração das peças, na maioria dos exemplares apresentados, foram utilizadas pastas vermelhas, compactas e homogéneas, com elementos não plásticos de grão médio e fino, nomeadamente quartzos e micas. Podemos encontrar este tipo de pasta em 12 dos fragmentos referidos, nomeadamente em cinco taças carenadas vidradas, quatro taças com cordões verticais, na taça esmaltada a verde com a representação da mão de Fátima, na panela e alguidar. O segundo tipo de pasta predominante caracteriza-se por ser uma pasta clara, muito homogénea e compacta, com elementos não plásticos de grão finíssimo, podendo-se encontrar nos dois testos, no fragmento de jarra vidrada a verde, no fragmento de jarra vidrada a branco com reflexo dourado e numa taça vidrada a verde.

Um outro tipo de pasta que também se observou nas peças é uma pasta alaranjada, compacta e homogénea, com elementos não plásticos de grão médio e fino, nomeadamente quartzos e mica, podendo-se encontrar nas duas candeias e numa taça vidrada a melado, assim como no fragmento de lamparina. Pastas de tom bege, compactas e homogéneas, com elementos não plásticos de grão médio e fino com quartzos e mica foram descobertas nos três fragmentos de talhas analisadas e no fogareiro. Pastas claras, muito homogéneas e compactas, com engobe negro e elementos não plásticos de grão finíssimo foram encontradas nos dois fragmentos de jarra esgrafitada com linha de vidrado verde.

Pastas vermelhas, muito homogéneas e compactas, com elementos não plásticos de grão finíssimo foram observadas em duas taças, nomeadamente na taça carenada e vidrada a melado com decoração a manganês e, na taça hemisférica, esmaltada a verde claro na superfície interna e turquesa na superfície externa. Por último, pasta clara de tom bege, compacta e homogénea, com elementos não plásticos de grão médio e fino, nomeadamente feldspato, mica e pedaços triturados de argila foi encontrada no fragmento de pia de abluções.

No que respeita às técnicas decorativas há um predomínio claro dos vidrados, dado que estes foram empregues em 19 peças, nomeadamente vidrado de cor castanha e aspecto melado, que é o prevalecente, seguido do vidrado verde e por último o branco, podendo-se encontrar estes vidrados em taças, jarras, candeias, lamparina e talhas. A segunda técnica predominante é o estampilhado aplicado sobre o vidrado ou esmaltado e sobre as pastas, tendo sido executado em 6 exemplares, nomeadamente na taça esmaltada a verde com representação da "mão de Fátima", no fragmento de jarra vidrada a verde e nos três fragmentos de talhas. Outras técnicas utilizadas foram a pintura, empregue em dois fragmentos de jarra e numa taça vidrada de cor castanha e aspecto melado, o esgrafitado que está presente em dois fragmentos de jarras, as caneluras aplicadas numa taça vidrada e numa panela, o relevo utilizado num fragmento de jarra com reflexo dourado e o inciso num fragmento de talha. Seis das peças não apresentam qualquer um dos motivos decorativos mencionados, nomeadamente algumas taças com cordões verticais, o fragmento de alguidar, os dois testos e o fogareiro. 


\section{APROXIMAÇÃO AO CONHECIMENTO DO ESPAÇO E DO QUOTIDIANO}

O conhecimento do espaço de onde provêm os materiais cerâmicos analisados tornase de difícil percepção. O estudo do espólio recolhido no interior do compartimento da habitação, permitiu atribuir-lhe uma datação, entre segunda metade do século XII e a primeira metade do século XIII, cronologia correspondente ao Período Almóada. No entanto, torna-se impossivel perceber a que tipo de compartimento corresponderia, não só pela ausência de dados referentes às camadas estratigráficas, como também pela intensa ocupação humana que a zona da alcáçova teve ao longo dos séculos, traduzindo-se essa presença no local numa série de sobreposições de estruturas e desmantelamento de outras para a edificação de novas construções, dificultando imenso a leitura do sítio.

A disposição dos muros e a localização num deles de abertura para o escoamento de águas pluviais, permite colocar a hipótese do compartimento corresponder a um pátio. A abertura localizada num dos muros é semeIhante às existentes em alguns dos pátios do Bairro Islâmico de Mértola, sendo frequente a localização daquelas nesses locais para expulsar as águas excedentes provenientes das chuvas. Para além disso, durante as intervenções arqueológicas não se encontraram fragmentos de telhas no seu interior, o que poderá indicar que se trataria de um espaço descoberto (FARIA e PAIXÃO, 1996: pp. 9-25; GOMES, 2003: p. 109; MACIAS, 2006: 397). Todavia, é meramente uma hipótese que carece de comprovação arqueológica. Somente a análise de todas as estruturas identificadas dos restantes sectores intervencionados, assim como do respectivo espólio associado, poderão dar algumas respostas mais concretas sobre a funcionalidade deste compartimento.

O espólio analisado testemunha o quotidiano desse espaço, as taças que se encontram em maior representatividade no conjunto, eram normalmente utilizadas para colocar os alimentos que depois eram servidos à mesa nos salões, enquanto as mais fundas e de menor diâmetro poderiam servir para conter líquidos, tal como as jarras que eram também destinadas a conter aquele elemento e poderiam ser, quer de uso individual, quer de uso colectivo, sendo tapadas com tampa ou testo (GOMES, 2002: p. 35; GÓMEZ MARTíNEZ, 2014a: p. 123). Duas das taças mostram marcas de fogo, tendo sido substituídas as suas funções iniciais destinadas ao serviço de mesa para passarem a ser utilizadas, possivelmente, como frigideiras para cozinhar.

Era também habitual haver nos pátios das casas, uma ou mais talhas, para servir os habitantes nas actividades domésticas e até para se refrescarem nos dias de calor em que o corpo necessitava de ser hidratado com maior frequência, sendo, normalmente, utilizadas para este fim as talhas vidradas, enquanto as restantes serviam para o armazenamento de produtos alimentares, enquadrando-se possivelmente, dois dos fragmentos de talha neste grupo, enquanto a talha vidrada a verde estampilhada serviria para conter água (GÓMEZ MARTÍNEZ, 2001b: p. 66; GOMES, 2003: p. 251; PALAZÓN e CASTILLO, 2003: p. 107; TORRES, 2011: p.132).

Para preparar os alimentos e cozinhá-los usavam-se normalmente, sobretudo na última fase da ocupação islâmica, fogareiros que eram colocados ao ar livre nos pátios, servindo este contentor de fogo como fogão ou grelha para assar ou até mesmo como braseira para o aquecimento doméstico (GÓMEZ MARTíNEZ, 2011: p. 77).

O lume fornecia calor estável e duradouro, dado que o mesmo ardia lentamente sob a forma de brasas, economizando tempo e permitindo uma cozedura lenta e apurada dos alimentos. Um fragmento de panela e alguidar que também foram encontrados neste espaço, serviam igualmente para essas actividades, a panela era utilizada para cozinhar, enquanto o alguidar poderia ser usado para preparar os alimentos e para a lavagem da loiça (GOMES, 2002: p. 37-38; GÓMEZ MARTÍNEZ, 2014a: p. 105).

Todas estas actividades necessitavam de iluminação, assim como a deslocação 
dentro dos vários compartimentos da casa, utilizando-se, por isso, candis e, sobretudo, no Período Almóada, generalizou-se o uso das candeias, que eram recipientes mais abertos, e lamparinas que possuíam uma base de prato, servindo ambos para iluminar (GÓMEZ MARTÍNEZ, 2001a: p. 160; GOMES, 2002: p. 41).

Era habitual também, a existência de pias para abluções no interior das habitações, conforme demonstra o fragmento referido, dado que as cinco orações diárias que um muçulmano devia cumprir com os respectivos rituais de purificação, nomeadamente as abluções, podiam ser realizadas igualmente em casa e não somente na mesquita (GÓMEZ MARTÍNEZ, 2014a: p. 170).

Para além dos quotidianos, estas peças demonstram igualmente a riqueza dos habitantes da alcáçova, dado que para adquirir alguns destes exemplares teriam de possuir meios económicos para importar este tipo de peças com várias decorações, desde vidrados, a estampilhados, esgrafitados, reflexos metálicos de outras zonas do al-Andalus que ali chegariam por via marítima, sendo comercializados no suq e depois adquiridos por estas elites para uso no quotidiano ou meramente função decorativa. Para além destas, também havia peças de produção local, conforme parecem sugerir os dois fragmentos encontrados de taças com cordões, sem qualquer tipo de vidrado, sendo esta hipótese ainda reforçada pela existência de várias ruas das olarias distribuídas pela cidade, nomeadamente as duas Ruas do Forno e Rua das Escadinhas do Forno, denunciando a existência deste tipo de actividades artesanais (LEITÃO, 2015: p. 93).

\section{CONCLUSÃO}

O espólio analisado proveniente do compartimento habitacional identificado no interior da alcáçova Muçulmana, permitiu datar aquela estrutura do Período Almóada. Possibilitou, igualmente, vislumbrar um pouco dos quotidianos, assim como da riqueza dos seus habitantes, dado que para obter-se algumas das peças mais elaboradas e claramente de importação, os residentes teriam de possuir meios económicos para as adquirir. Por outro lado, temos também peças produzidas localmente, como as taças de cordão vertical não vidradas.

Os modelos das peças descritas enquadram-se, como podemos verificar, nas formas típicas do período enunciado, podendo-se encontrar vários paralelos nas outras zonas do al-Andalus. Este aspecto deve-se, não só, à estandardização da cerâmica nesta fase, mas também aos circuitos comerciais que Alcácer do Sal tinha com as outras cidades, estabelecendo-se essa ligação através das vias terrestres e, sobretudo, por via marítima, graças ao rio Sado, que era, sem dúvida, a grande estrada por onde se deslocavam os produtos e os mercadores.

\section{BIBLIOGRAFIA}

BEDIA, Juana; MACIAS, Juan Aurelio Pérez (1993): "Un lote de cerâmica islámica de Niebla”, Arqueologia Medieval, no 2. Porto, Edições Afrontamento, pp. 55-62.

CARVALHO, A.R., FARIA, J.C., (1994): "Cerâmicas muçulmanas do Museu Municipal de Alcácer do Sal”, Arqueologia Medieval, 3. Porto, Edições Afrontamento, pp. 101-111.

CARVAlHO, A. R. ; PAIXÃO, A. M. C., (2001): "Cerâmicas almoadas de al-Qasr al-Fath (Alcácer do Sal), Garb: Sítios islâmicos do Sul Peninsular. Lisboa/Mérida, IPPAR/Junta da Extremadura, pp. 199-229.

CATARINO, Helena (1997): O Algarve Oriental Durante a Ocupação Islâmica: Povoamento Rural e Recintos Fortificados. Dissertação de Doutoramento em Arqueologia apresentada à Unniversidade de Coimbra.

CATARINO, Helena; Cavaco, Sandra; Covaneiro, Jaquelina; Fernandes, Isabel Cristina; Gomes, Ana; Gómez Martínez, Susana; Gonçalves, Maria José; Grangé, Mathieu; Inácio, Isabel; Lopes, Gonçalo; Santos, Constança dos e Bugalhão, Jacinta (2012): "La céramique islamique du Garb al-Andalus: contextes socio-territoriaux et distribution", Atti del IX Congresso Internazionale sulla Ceramica Medievale nel Mediterraneo. Venezia 2009. Edizioni All’Insegna del Giglio. pp. 429-441.

FARIA, João Carlos Lázaro; PAIXÃO, António Cavaleiro (1996): Relatório das escavações arqueológicas no convento de Nossa Senhora de Aracaeli, Alcácer do Sal.

GOMES, Rosa Varela (1988): "Cerâmicas Muçulmanas do Castelo de Silves”, Xelb. Silves, Câmara Municipal de Silves.

GOMES, Rosa Varela (2002): Silves (Xelb) uma Cidade do Gharb Al-Andalus: Território e Cultura. Lisboa, Instituto Português de Arqueologia. 
GOMES, Rosa Varela (2003): Silves (Xelb) uma cidade do Gharb Al-Andalus: a Alcáçova. Lisboa, Instituto Português de Arqueologia.

GOMES, Rosa Varela (2013): Arquiteturas: Testemunhos Islâmicos em Portugal. Lisboa, Castelo de São Jorge.

GÓMEZ MARTÍNEZ, Susana (2000): "Contenedores de fuego en el Garb al-Adndalus", Actas do III Congresso de Arqueologia Peninsular. Vila Real de Trás-os-Montes, Setembro de 1999, vol. VII, "Arqueologia da Idade Média da Península Ibérica”, pp. 421-434, Porto, ADECAP.

GÓMEZ MARTíNEZ, Susana (2001a) : "Catalogo cerâmica « in MACIAS, Santiago ; TORRES, Cláudio (Coord.), Arte Islâmica. Mértola, Campo Arqueológico de Mértola, pp. 107-167.

GÓMEZ MARTÍNEZ, Susana (2001b) : "A cerâmica islâmica de Mértola" in MACIAS, Santiago ; TORRES, Cláudio (Coord.), Arte Islâmica. Mértola, Campo Arqueológico de Mértola, pp. 63-69.

GÓMEZ MARTÍNEZ, Susana (2005): "Cerámica a molde de época islâmica”, Arqueologia Medieval, no 9. Porto: Edições Afrontamento, pp. 221-232.

GÓMEZ MARTíNEZ, Susana (2006): "A cerâmica islâmica no Gharb al-Ândalus", Seminário a produção de cerâmica em Portugal: histórias com futuro. Mértola, Campo Arqueológico de Mértola, pp. 95-116.

GÓMEZ MARTÍNEZ, Susana; MACIAS, Santiago (2006): "La especificidad del Garb al-Andalus y su expresión en la vajilla almohade" in Patrice Cressier, Maribel Fierro e Luis Molina (eds.) - Los Almohades: problemas y perspectivas, vol. I, Madrid, Consejo Superior de Investigaciones Científicas e Casa de Velásquez, pp. 387-409.

GÓMEZ MARTíNEZ, Susana (Coord.) (2011): "As marcas do trabalho", Os Signos do Quotidiano: Gestos, Marcas e Símbolos no al-Andalus. Mértola, Campo Arqueológico de Mértola, pp. 65-82.

GÓMEZ MARTínEZ, Susana (2014a): Cerâmica Islámica de Mértola: Museu de Mértola. Mértola, Campo Arqueológico de Mértola.

GÓMEZ MARTíNEZ, Susana (Coord.) (2014b): Museu de Mértola. Catálogo Geral, Mértola, Campo Arqueológico de Mértola.
GONÇALVES, Maria José e Khawli, Abdallah (2008): “Um lote de cerâmica estampilhada de um arrabalde da Silves Islâmica", Actas do 40 Congresso de Arqueologia Peninsular. vol. XI - A ocupação islâmica da Península Ibérica. Promontoria Monográfica. Faro. Universidade do Algarve. pp. 175-192.

LEITÃO, Marta Isabel Caetano (2015): A Presença Islâmica em al-Qasr - Uma análise sobre o urbanismo e o sistema defensivo. Dissertação de Mestrado em Arqueologia apresentada à Faculdade de Ciências Sociais e Humanas da Universidade Nova de Lisboa.

MACIAS, Santiago (1996): Mértola Islâmica. Estudo Histórico-Arqueológico do Bairro da Alcáçova. Mértola. Campo Arqueológico de Mértola.

MACIAS, Santiago (2006) : Mértola - o último porto do Mediterrâneo Vol. I, II, III. Mértola, Campo Arqueológico de Mértola.

NAVARRO PALAZÓN, Julio (1986): La ceramica islamica em Murcia: volume I catálogo. Múrcia, Centro Municipal de Arqueologia e Ayuntamiento de Murcia.

NAVARRO PALAZÓN, Julio; JIMÉNEZ, Pedro Castillo (2003): "La cerâmica andalusí de Siyâsa. Estudio preliminar", Actas das 3 a Jornadas de cerâmica Medieval e Pós-Medieval. Tondela, Câmara Municipal de Tondela, pp. 103-123.

PAIXÃO, António; FARIA, João Carlos; CARVALHO, António Rafael (1994): "O Castelo de Alcácer do Sal. Um projecto de arqueologia urbana", Bracara Augusta, Actas do Encontro de Arqueologia Urbana de Braga, vol. XLV, no 97 (110), pp. 215-264.

PAIXÃO, António; FARIA, João Carlos; CARVALHO, António Rafael (2001): "Contributo para o estudo da ocupação muçulmana no castelo de Alcácer do Sal: o Convento de Aracoelli", Arqueologia Medieval, no 7, Porto, Edições Afrontamento, pp. 197-209.

PAIXÃO, António Cavaleiro; FARIA, João Carlos; CARVALHO, A. Rafael (2001): "Aspectos da presença Almóada em Alcácer do Sal (Portugal)", Mil Anos de Fortificações na Península Ibérica e no Magreb (5000-1500). Actas sobre o Simpósio Internacional sobre Castelos, Lisboa / Palmela, Edições Colibri / Câmara Municipal de Palmela, pp. 369-383.

TORRES, Nádia (2011): O desenho na cerâmica islâmica de Mértola. Mértola, Campo Arqueológico de Mértola. 